DOI https://doi.org/10.18551/rjoas.2018-09.19

\title{
THE EFFECT OF CREDIT AND LIQUIDITY RISK ON BANK PROFITABILITY AND CAPITAL ADEQUACY RATIO AS MEDIATION VARIABLES IN INDONESIA
}

\author{
Ariwidanta K.T., Wiksuana I.G.B. \\ Postgraduate Program, University of Udayana, Bali, Indonesia \\ *E-mail: triskaari44@gmail.com
}

\begin{abstract}
This study aims to determine the relationship between credit and liquidity risk to profitability through the capital adequacy ratio as a mediating variable. The population in this study was 43 Indonesian banks listed on the Indonesia Stock Exchange. The method in determining the sample uses purposive sampling and obtained 26 banking companies that meet the sample criteria. Data in the study are secondary data. The data analysis technique used is Path Analysis. The results of this study found that credit risk has a negative and significant effect on profitability, liquidity has a positive and significant effect on profitability, credit risk has a negative and significant effect on the capital adequacy ratio, liquidity has a positive and insignificant effect on the capital adequacy ratio, capital adequacy ratio has a positive and not significant to profitability. As well as the capital adequacy ratio is not able to mediate the effect of credit and liquidity risk on profitability. This research can provide information to be considered by banks in Indonesia to maintain the standard provisions for financial ratios that have been implied by Bank Indonesia.
\end{abstract}

\section{KEY WORDS}

Credit risk, liquidity, capital adequacy ratio, profitability.

Banks in carrying out their operational activities have the main objective, namely to achieve maximum profitability. Profitability is the ability of banks to generate profits effectively and efficiently. Sartono (2014: 123) states that profitability is the company's ability to make a profit in relation to sales, total assets and own capital. High bank profitability reflects that banks have a good system in risk management, credit checks, and risk monitoring which is expected to reduce bank risks (Chatarine, 2016). Return on Assets (ROA) is a ratio in measuring profitability. Although there are various profitability assessment indicators that are often used by banks, ROA is a ratio that shows the return (return) of the amount of assets used in the company (Kasmir, 2016: 115).

The phenomenon of an increase in the ratio of Non-Performing Loans which is a proxy of credit risk indicates the cause of a decline in Indonesia's banking profitability. Increasing Loan to Deposit Ratio, which is a proxy of liquidity, explains that the higher the loan, the higher the funds disbursed. With the large distribution of funds back to the community, income has increased.

One of the bank's main activities to increase profitability is by providing credit. Credit disbursement is one of the highest profits obtained by the bank, if it is estimated that it can reach 90 percent of bank profits obtained from credit (Fahmi, 2014: 57). But in addition to being a good source of income, this lending activity is vulnerable to risks that can be one of the main causes of banks facing problems and leading to bankruptcy. Banks must be careful in determining the feasibility of who is entitled to receive credit so that they can anticipate bad loans. Credit risk has an important role in profitability because a decrease in bank income arises from the interest on loans obtained.

Credit Risk which is proxied by NPL (Non-Performing Loan) serves to measure the bank's ability to cover the risk of failure of credit repayment by the debtor. The amount of the NPL percentage must be the concern of the management because of the increasing problem loans that could endanger the health of the bank. Loans channeled by banks have a risk of default by the debtor. The amount of NPL allowed by Bank Indonesia is currently a maximum 
of $5 \%$. The greater the level of NPL indicates that the bank is not professional in managing its credit which will have an impact on the bank's losses (Septiani and Lestari, 2016).

The bank's ability to manage its liquidity will have an impact on the public's trust in the bank so that it will help the operational continuity and the existence of the bank. Technically, liquidity can be interpreted as a company's continuous ability to meet short-term debt (Uramedu et al, 2012). To measure bank liquidity, proxied by the Loan to Deposit Ratio (LDR). The LDR ratio is the composition of the ratio between the amount of credit disbursed and the amount of funds used, the bank's own capital and the public funds collected (Kasmir, 2011: 25). The LDR also shows the ability of a bank to repay customers' obligations by channeling funds or providing credit to customers. If there is an increase in the LDR percentage, this is because the volume of bank lending increases and the automatic interest payments obtained by banks also increase, (Septiani and Lestari, 2016).

Capital in banks has a very important role. Capital adequacy can be measured using the Capital Adequacy Ratio (CAR). It is important for the management to pay attention to the amount of CAR that is owned so that the bank is not short of funds and also does not have excess funds. Capital is the main source of financing for bank operations and also acts as a buffer against possible risk of loss. The greater the capital owned, the stronger the bank will be in dealing with unexpected risks so that banks can increase public trust, (Anjani and Purnawati, 2014 in Septiani and Lestari, 2016). However, banks that have a CAR that is too high can result in idle funds, namely there are many idle funds that cannot be utilized by the bank's management. Bank capital consists of core capital and supplementary capital (Idroes, 2011: 68).

Banks that have large capital can get even greater profits. Research conducted by (Agustiningrum, 2013) explains that CAR has a positive effect on profitability. This means that the smaller the risk that the bank will provide a large profit for the bank. Research conducted by (Al-Qudah and Mahmoud, 2013) also found the positive between capital adequacy ratio and profitability. Banks that have high capital will achieve high profits because the bank is more careful in choosing financing sources. This is contrary to the results of the study (Poposka et al., 2013) and (Jha and Hui, 2012) states that CAR has a negative effect on ROA. Banks that have high capital and face quite tight competition will focus more on increasing assets owned along with the bank's increasing capital. To achieve the desired growth with intense competition, the bank will reduce the spread or the difference from the interest on loans with the interest collected, so that it can reduce profitability (Maheswari and Surya, 2014). Based on previous research, there is still a gap in the difference between the relationship between CAR and ROA.

\section{LITERATURE REVIEW}

The financial performance of a bank is considered healthy and can be seen from the level of profitability. The main indicator used as a basis for evaluating a bank's financial performance is financial statements. Based on financial statements, banks can calculate a number of financial ratios that are commonly used as a basis for evaluating company performance. Financial ratio analysis is one tool for estimating or knowing the performance of a bank. If financial performance increases, the value of the company will be even higher. The Bank provides financial statements to show information and financial positions presented to interested parties such as creditors, investors, customers and Bank Indonesia as the bank supervisory authority to evaluate bank performance (Puspitasari, 2009).

According to Rax (1996: 24) Asset and Liability Management is a process of planning and monitoring banking operations that are coordinated and consequently carried out by always paying attention to the development of factors that affect banking operations, whether from outside or structural originating from within.According to Riyadi (2006: 21) Asset and Liability Management is a process of planning, organizing, actuating, and controlling to get policy decisions in the field of management: Capital (equity); Funding; Use of funds (assets).

Each other is interrelated in achieving optimal profit levels with calculated risk levels. 
The discussion of GAP is one of the important discussions in ALMA. According to Riyadi (2006: 133) GAP is the difference between Assets that are sensitive to changes in interest rates (Rate Sensitive Assets) and liabilities that are sensitive to changes in interest rates (Rate Sensitive Liability). For banks today, GAP management is important. This is due to the level of interest rate volatility which is very sensitive to changes. With the condition of the level of interest rate changes, the banking world, especially in managing resources and the use of funds or assets and liability management, is in dire need of a system that can function and play a role in monitoring and controlling the sensitive interest rate movements.

According to Riyadi (2006: 155) states that the profitability of a bank shows a comparison of profit after tax with core capital or profit before tax with total assets owned by the bank in a certain period. Profitability is an assessment that reflects the ability of each company to generate profits and determine the credibility of a bank and the effectiveness of the bank concerned. Managerial performance of each banking system can be said to be good if the level of profitability of banking companies that are managed is high or maximal (Elviani, 2010).

According to Taswan (2010: 214), bank capital is a fund invested by the owner in the framework of establishing a business entity that is intended to finance the bank's business activities in addition to fulfilling the regulations set by the monetary authority. According to Idroes (2011: 73), the capital adequacy ratio is a ratio that aims to ensure that banks can absorb losses arising from their activities. In measuring capital adequacy, an indicator of Capital Adequacy Ratio (CAR) can be used, which is a ratio to measure the ability of capital from a bank and bank management to reduce risks or losses resulting from credit activities and securities trading. CAR is a comparison of assets that contain risks so it is necessary to first know the size of the estimation of the risks that occur in granting credit.

According to Bank Indonesia regulation No. 5 of 2013, risk is the potential for events (events) that can cause losses, one of the bank's business risks is credit risk. Credit risk is a risk arising from counterparty failure (other parties) fulfilling obligations. In the banking Act No. 10 of 1998 Article 21 Paragraph 11, the definition of credit is the provision of money or equivalent claims, based on an interbank loan agreement or agreement with another party that requires the borrower to repay the debt after a certain period of time with the provision of credit. Credit, besides creating risk, also creates income. Credit income can be in the form of interest or revenue sharing (Taswan, 2010: 309).

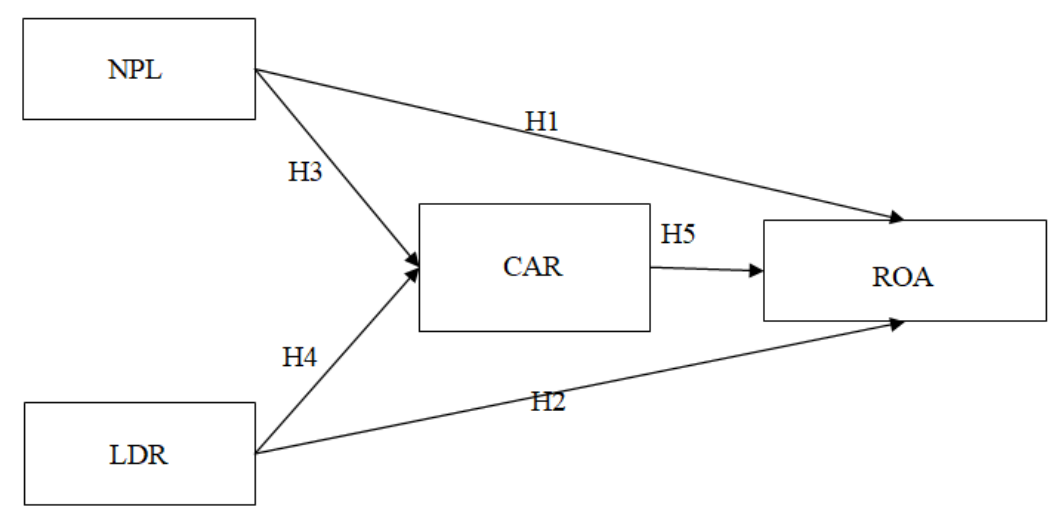

Figure 1 - Conceptual Framework

The liquidity ratio can be measured using the loan to deposit ratio (LDR). LDR is a comparison between the total credit that has been given by the bank and the total third part funds that can be collected by banks (Riyadi, 2006: 165). LDR states the ability of a bank to pay back customer-owned funds embedded in the bank by relying on credit channeled as a source of liquidity (Pauzi, 2010). The higher the LDR gives an indication of the lower liquidity capacity of the bank, because the amount of funds needed to finance credit is greater. According to Bank Indonesia, banks are considered healthy if the amount of the LDR is 
between $85 \%$ and $110 \%$. If it is above $110 \%$, the bank will experience liquidity difficulties and have an impact on the bank's profitability and performance.

Hypotheses:

$\mathrm{H} 1$ : Credit risk has a negative and significant effect on profitability;

$\mathrm{H} 2$ : Liquidity has a positive and significant effect on profitability;

H3: Credit risk has a negative and significant effect on capital adequacy;

$\mathrm{H} 4$ : Liquidity has a positive and significant effect on capital adequacy;

H5: Capital adequacy has a positive and significant effect on profitability;

H6: Capital adequacy is able to mediate the effect of credit risk on profitability;

H7: Capital adequacy can mediate the effect of liquidity on profitability.

\section{METHODS OF RESEARCH}

The research design used in this study is causality research. Causality research in this study is about the effect of credit risk and liquidity on profitability with capital adequacy as a mediating variable. This research was conducted by accessing the official website of the Indonesia Stock Exchange (IDX) at www.idx.co.id. The site provides financial report information. Data collection methods used in this study are nonparticipant observation methods, namely data collection methods with observations where researchers are not directly involved and only as independent observers (Sugiyono, 2011: 204). The analysis technique used in this research is path analysis technique. Path analysis is a statistical analysis developed from multiple regressions. Path analysis model is used to analyze the pattern of relationships between variables in order to determine the direct or indirect effects of a set of independent (exogenous) variables on the dependent variable (endogenous).

\section{RESULTS AND DISCUSSION}

Data analysis uses path analysis model with the help of Multiple Linear Regression and the software used is SPSS 22.0 for available data with ROA endogenous variables through CAR mediation variables and exogenous variables namely NPL and LDR.

Table 1 - Path Coefficient Equation to Capital Adequacy Ratio

\begin{tabular}{|c|c|c|c|c|c|c|}
\hline \multirow{2}{*}{\multicolumn{2}{|c|}{ Model }} & \multicolumn{2}{|c|}{ Unstandardized Coefficients } & \multirow{2}{*}{$\begin{array}{l}\text { Standardized Coefficients } \\
\text { Beta }\end{array}$} & \multirow[t]{2}{*}{$\mathrm{t}$} & \multirow[t]{2}{*}{ Sig. } \\
\hline & & $\mathrm{B}$ & Std. Error & & & \\
\hline \multirow[t]{3}{*}{1} & (Constant) & 17,445 & 2,033 & & 8,582 & ,000 \\
\hline & NPL &,- 548 & ,187 &,- 253 & $-2,927$ & ,004 \\
\hline & LDR & 017 & 023 &, 061 & ,704 & ,483 \\
\hline
\end{tabular}

Source: Primary data, 2017.

The equation can be written as follows:

$$
Y 1=-0,253 X 1+0,061 X 2
$$

The NPL variable coefficient is obtained at -0.253 , meaning that if the NPL experiences an increase, the CAR tends to decrease. The coefficient of the LDR variable is obtained at 0.061 which means that if the LDR increases then CAR tends to decrease.

Table 2 - Path Coefficient Equation to ROA

\begin{tabular}{|c|c|c|c|c|c|c|}
\hline \multirow{2}{*}{\multicolumn{2}{|c|}{ Model }} & \multicolumn{2}{|c|}{ Unstandardized Coefficients } & \multirow{2}{*}{$\begin{array}{l}\text { Standardized Coefficients } \\
\text { Beta }\end{array}$} & \multirow[t]{2}{*}{$t$} & \multirow[t]{2}{*}{ Sig. } \\
\hline & & $\mathrm{B}$ & Std. Error & & & \\
\hline \multirow[t]{4}{*}{1} & (Constant) & ,702 & ,811 & & ,866 & ,388 \\
\hline & NPL &,- 269 & 061 &,- 368 & $-4,392$ &, 000 \\
\hline & LDR &, 015 &, 007 &, 165 & 2,035 & 044 \\
\hline & CAR & ,037 & ,028 & 109 & 1,309 & 193 \\
\hline
\end{tabular}

Source: Primary Data, 2018. 
The equation can be written as follows:

$$
Y 2=-0,368 X 1+0,165 X 2+0,109 Y 1
$$

The NPL variable coefficient is obtained at -0.38 , meaning that if the NPL experiences an increase, ROA tends to decrease. The coefficient of the LDR variable is obtained at 0.165 , meaning that if the LDR increases, ROA tends to increase. The CAR variable coefficient is obtained at 0.109 , meaning that if CAR has increased, ROA tends to increase.

Table 3 - Indirect Effect and Total Effect of NPL, LDR to CAR and ROA

\begin{tabular}{llll}
\hline Variable & Direct Effect & Indirect Effect & Total Effect \\
\hline$X_{1} \rightarrow Y_{2}$ & $-0,368$ & $-0,027$ & $-0,395$ \\
$X_{2} \rightarrow Y_{2}$ & 0,165 & 0,006 & 0,171 \\
$X_{1} \rightarrow Y_{1}$ & $-0,253$ & - & $-0,253$ \\
$X_{2} \rightarrow Y_{1}$ & 0,061 & - & 0,061 \\
$Y_{1} \rightarrow Y_{2}$ & 0,109 & - & 0,109 \\
\hline
\end{tabular}

Source: Primary data, 2018.

Calculation of variant variables that are not examined in the model can be shown by the following equation:

$$
\begin{array}{ll}
\mathrm{e}_{1}=\sqrt{1-\mathrm{R}^{2}} & \mathrm{e}_{2}=\sqrt{1-\mathrm{R}^{2}} \\
\mathrm{e}_{1}=\sqrt{1-0,050} & \mathrm{e}_{2}=\sqrt{1-0,163} \\
\mathrm{e}_{1}=0,974 & \mathrm{e}_{2}=0,914
\end{array}
$$

Based on the results of the calculation above, e1 is obtained at 0.974 and e2 at 0.914 . Evaluation of the validity of the model in the path analysis can be seen from the total determination coefficient of the structural equation from the following research model:

Table 4 - Capital Adequacy Ratio Determination Coefficient Testing Result

\begin{tabular}{lllll}
\hline Model & $\mathrm{R}$ & $\mathrm{R}$ Square & Adjusted R Square & Std. Error of the Estimate \\
\hline 1 &, $253^{\mathrm{a}}$ &, 064 &, 050 & 2,740238 \\
\hline
\end{tabular}

Source: Primary data, 2018.

Table 5 - ROA Determination Coefficient Testing Result

\begin{tabular}{lllll}
\hline Model & $\mathrm{R}$ & $\mathrm{R}$ Square & Adjusted R Square & Std. Error of the Estimate \\
\hline 1 &, $427^{\mathrm{a}}$ &, 182 &, 163 &, 869213 \\
\hline
\end{tabular}

Source: Primary data, 2018.

$$
\begin{gathered}
\mathrm{R}^{2}{ }_{1}=0,050 \\
\mathrm{R}^{2}{ }_{2}=0,163 \\
\mathrm{Pe}=\sqrt{1-\mathrm{R}^{2}}
\end{gathered}
$$

Obtained:

$$
\begin{aligned}
& \mathrm{Pe}_{1}=\sqrt{1-0,050}=\sqrt{0,95}=0,974 \\
& \mathrm{Pe}_{2}=\sqrt{1-0,163}=\sqrt{0,837}=0,914
\end{aligned}
$$

Determination Coefficient Total $\left(R^{2} \mathrm{~m}\right)$ :

$$
R^{2} m=1-\left(\mathrm{Pe}_{1}^{2} \times \mathrm{Pe}_{2}{ }^{2}\right)=1-\left(0,974^{2} \times 0,914^{2}\right)=0,207
$$

The total determination coefficient of the structural equation of the research model in accordance with the calculations obtained R2m value of 0.207 means that by 20.7 percent 
the information contained can be explained by the model formed, while the remaining 79.3 percent is explained by variables outside the model formed.

The results of testing the effect of the NPL variable on ROA shows the path coefficient of -0.336 with a significance value of $0.000<0.05$. Significant value less than 0.05 indicates that NPL has a negative and significant effect on ROA. This means that: $\mathrm{H} 1$ is accepted.

The results of testing the effect of the LDR variable on ROA shows the path coefficient of 0.165 with a significance value of $0.044<0.05$. Significant value less than 0.05 indicates that LDR has a positive and significant effect on ROA. This means that: $\mathrm{H} 2$ is accepted.

he results of testing the effect of the NPL variable on CAR shows the path coefficient of -0.253 with a significance value of $0.004<0.05$. Significant value less than 0.05 indicates that NPL has a negative and significant effect on CAR. This means that: $\mathrm{H} 3$ is accepted.

The results of testing the effect of the LDR variable on the CAR shows the path coefficient of 0.061 with a significance value of $0.483>0.05$. Significance values greater than 0.05 indicate that the LDR has a positive and insignificant effect on CAR. This means that: $\mathrm{H} 4$ is rejected.

The results of testing the effect of the variable CAR on ROA shows the path coefficient of 0.109 with a significance value of $0.193>0.05$. A significance value greater than 0.05 indicates that CAR has a positive and insignificant influence on ROA. This means that: H5 is rejected.

The result of testing the CAR variable as a mediating effect of NPL on ROA shows the path coefficient of -0.027 , while the direct effect between NPL and ROA is -0.336 . The magnitude of the path coefficient the direct effect of NPL on ROA compared to the indirect effect of NPL on ROA through CAR shows that CAR is not able to act as a mediating variable. This means that: $\mathrm{H} 6$ is rejected.

The test results of the CAR variable as a mediating effect of LDR on ROA shows the path coefficient of 0.006 , while the direct effect between LDR on ROA is 0.165 . The magnitude of the path coefficient of the direct influence of LDR on ROA compared to the indirect effect of LDR on ROA through CAR shows that CAR is not able to act as a mediating variable. This means that: $\mathrm{H} 7$ is rejected.

\section{CONCLUSION}

Credit risk has a negative and significant effect on profitability. This shows that the higher the credit risk, the lower the chances of the bank in making funds turnover in obtaining profits which causes a decrease in profitability.

Liquidity has a positive and significant effect on profitability. This shows that the increased volume of loans disbursed will provide greater interest income, thereby increasing profitability.

Credit risk has a negative and significant effect on the capital adequacy ratio. This shows the high number of non-performing loans will increase the Allowance for Earning Assets (PPAP) from the equity held, thus reducing the share of equity which is a component of capital adequacy.

Liquidity has a positive and insignificant effect on the capital adequacy ratio. This shows that credit increases in the volume of loans disbursed causes banks to have a greater ability to repay funds collected from the community, so that banks do not need to use their capital as a source of financing.

The effect of the capital adequacy ratio on positive and insignificant influence. This shows that high capital will protect banks from the risks that will be faced, so that banks can improve their performance which results in increased profitability.

The capital adequacy ratio is unable to mediate the effect of credit risk on profitability. This is because to increase profitability it is better to do it directly with low credit risk. This means that capital reserves are not necessarily needed to cover losses due to the high level of credit risk, because of the efforts in credit restructuring one of which is done by taking over collateral. 
The capital adequacy ratio is not able to mediate the effect of liquidity on profitability. This shows that increasing profitability is better done directly by increasing liquidity. This means that in increasing the profitability of interest income on lending, banks do not need capital reserves because a high liquidity ratio indicates that more and more third part funds are channeled into loans.

\section{REFERENCES}

1. Agustiningrum, R. 2013. AnalisisPengaruh Car, Npl, Dan Ldr Terhadap Profitabilitas Pada Perusahaan Perbankan. E-Jurnal Manajemen Universitas Udayana, 2(8): 885-902.

2. Al-Qudah, Ali Mustafa and Mahmoud Ali Jaradat. The Impact of Macroeconomic Variables and Banks Characteristics on Jordanian Islamic Banks Profitability: Empirical Evidence. International Business Research, 6(10): pp: 153-162.

3. Chishty, K.A. (2011). The Impact of Capital Adequacy Requirements on Profitability of Private Banks in India (A Case Study of J\&K, ICICl, HDFC, \& Yes Bank). International Journal of Research in Commerce \& Management, 2(7), July.

4. Elviani, Sri. 2010. Pengaruh Risiko Kredit yang Diberikan dan Tingkat Likuiditas Terhadap Profitabilitas Perusahaan Perbankan yang Terdaftar Di Bursa Efek Indonesia. Jurnal Ekonomi dan Bisnis Islam: h: 971-1000.

5. Fahmi, Irham. (2014). AnalisisLaporanKeuangan. Bandung: Alfabeta.

6. Idroes, Ferry N. 2011. Manajemen Risiko Perbankan: Pemahaman Pendekatan 3 pilarkesepakatan Basel II Terkait Aplikasi Regulasi dan Pelaksanaannya di Indonesia. Jakarta: Rajawali Pers

7. Jha, Suvita, and Xiaofeng Hui. 2012. A Comparison of Financial Performance of Commercial Banks: A Case Study of Nepal. African Journal of Business Management, 6(25), pp: 7601-7611.

8. Kasmir, 2016. Analisis Laporan Keuangan. Cetakan 9. Jakarta: PT Rajagarfindopersada.

9. Kasmir. 2012. Bank dan Lembaga KeuanganLainnya. Jakarta: PT Raja Grafindo Persada

10. Maheswari, Kadek Indah. 2014. Pengaruh NPL terhadap ROA dengan Mediasi CAR dan BOPO Pada Perbankan Indonesia. E-Jurnal Program Studi Manajemen Fakultas Ekonomi dan Bisnis Universitas Udayana, 3(4), hal: 1119-1139.

11. Pauzi, Agus. 2011. Analisis Dana PihakKetiga, Non Performing Loan, Capital Adequecy Ratio, Dan Loan to Deposit Ratio Terhadap Return on Assets Serta Implikasinya Terhadap Penyaluran Kredit Pada Bank Persero. Skripsi. Jurusan Manajemen Fakultas Ekonomi Dan Bisnis Universitas Islam Negeri Syarif Hidayatullah, Jakarta.

12. Poernamawatie, Fahmi. 2009. Pengaruh Risiko Kredit Terhadap Kinerja Keuangan pada Bank-Bank Persero yang Terdaftar di BEl. Jurnal Manajemen Gajana, 6(1): h: 71-90.

13. Poposka, Klimentina, and Marko Trpkoski. 2013. Secondary Model for Bank Profitability Management-Test on the Case of Macedonian Banking Sector. Research Journal of Finance and Accounting, 4(6), pp: 216-225.

14. Puspitasari, Diana. 2009. AnalisisPengaruh CAR, NPL, PDN, NIM, BOPO, LDR, dan SukuBunga SBI terhadap ROA. Tesis. Universitas Diponegoro, Semarang.

15. Rax, Raflus. 1996. Asset-Liability Management. Jakarta

16. Riyadi, Selamet. 2006. Banking Assets and Liability Management EdisiKetiga. Lembaga Penerbit Fakultas Ekonomi Universitas Indonesia.

17. Sartono, A. 2014. Manajemen Keuangan Teori dan Aplikasi. EdisiKeempat. BPFE. Yogyakarta.

18. Septiani, Rita dan Lestari Putu Vivi. 2016. Pengaruh NPL dan LDR terhadap Profitabilitasdengan CAR sebagai Variabel Mediasi pada PT. BPR Pasaraya Kuta. JurnalManajemen Vol. 5 No. 1.

19. Sugiyono, 2014. MetodePenelitianBinis. Bandung. Alfabeta

20. Taswan. 2010. Manajemen Perbankan Konsep, Teknik dan Aplikasi. Yogyakarta: UPP STIM YKPN. 